\title{
The Effect of Social Media-Supported Teaching on Students Satisfaction Levels: A Case Study of Instagram
}

\author{
Güler KARAMAN*, Esra ÖZMEN**
}

Received date: 23.12.2019

Accepted date: 22.08.2021

\begin{abstract}
In this study, satisfaction levels of students were examined as a result of supporting the formal undergraduate courses with social media (Instagram) shares. The sample of this study consists of 2nd and 3rd grade undergraduate students of "Atatürk University Faculty of Economics and Administrative Sciences". One course for each group of those students were tried to be supported via Instagram application, which is one of the social media tools. During the semester, for the courses of Decision Support Systems and Introduction to Algorithms and Programming, various posts were shared through Instagram account which is signed up for the teaching purpose by the lecturer of the course. At the end of the semester, data were collected through an evaluation questionnaire that examines the satisfaction levels of students for the course sharing on Instagram account. The data within the scope of the study were collected in the spring semester of the 2018-2019 Academic Year. In this mixed research study, a satisfaction questionnaire was used to collect both qualitative and quantitative data. The questionnaire includes 7-point Likerttype items and open-ended questions. While quantitative data obtained from 180 participant students were analyzed with SPSS software, NVivo software was used for the analysis of qualitative data. As a result of the analysis of the quantitative data obtained, significant differences were found, especially in the context of gender and the courses. As a result of qualitative data analysis, it was concluded that the courses carried out formally ought to be supported with social media.
\end{abstract}

Keywords: Social media, social media-supported education, online education, distance education, lifelong learning

Ankara Hacı Bayram Veli University, Management Information Systems, Ankara, Turkey; karaman.guler@hbv.edu.tr

**(D) Ankara Hacı Bayram Veli University, Distance Education Application and Research Center, Ankara, Turkey; esra.ozmen@hbv.edu.tr 


\title{
Sosyal Medya Destekli Öğretimin Öğrenci Memnuniyet Düzeylerine Etkisi: Instagram Örneği
}

\author{
Güler KARAMAN*, Esra ÖZMEN**
}

Geliş tarihi: 23.12.2019

Kabul tarihi: 22.08.2021

\section{$\ddot{0} \mathbf{z}$}

Bu çalışmada örgün olarak yürütülen lisans derslerinin sosyal medya (Instagram) paylaşımları ile desteklenmesi sonucunda öğrencilerin memnuniyet düzeyleri incelenmiştir. Çalışmanın örneklemi "Atatürk Üniversitesi İktisadi ve İdari Bilimler Fakültesi" 2. ve 3. sınıf lisans öğrencilerinden oluşmaktadır. Sosyal medya araçlarından Instagram uygulaması ile her iki gruptaki öğrenciler için birer ders desteklenmeye çalışılmıştır. Yarıyıl boyunca Karar Destek Sistemleri ve Algoritma ve Programlamaya Giriş derslerine yönelik dersin öğretim üyesi tarafından öğretim amaçlı açılan Instagram hesabı üzerinden çeşitli paylaşımlar yapılmıştır. Dönem sonunda, Instagram hesabı üzerinden söz konusu derslere yönelik yapılan paylaşımlar için öğrencilerin memnuniyet düzeylerini inceleyen bir değerlendirme anketi ile veriler toplanmıştır. Çalışma kapsamındaki veriler 2018-2019 Eğitim Öğretim Yılı Bahar yarıyılında toplanmıştır. Karma araştırma deseni benimsenen bu çalışmada hem nitel hem de nicel verilerin toplanması için memnuniyet anketi kullanılmıştır. Anket 7'li Likert tipi maddeler ve açık uçlu sorular içermektedir. 180 katılımcı öğrenciden elde edilen nicel veriler SPSS yazılımı ile analiz edilirken, nitel verilerin analizi için NVivo yazılımı kullanılmıştır. Elde edilen nicel verilerin analizi sonucunda özellikle cinsiyet ve dersler bağlamında önemli farklılıklar bulunmuştur. Nitel veri analizi sonucunda örgün olarak yürütülen derslerin sosyal medya ile desteklenmesi gerektiği sonucuna varılmıştır.

Anahtar kelimeler: Sosyal medya, sosyal medya destekli eğitim, online eğitim, uzaktan eğitim, yaşam boyu öğrenme.

Ankara Hacı Bayram Veli Üniversitesi, Yönetim Bilişim Sistemleri, Ankara, Türkiye; karaman.guler@hbv.edu.tr

**(D) Ankara Hacı Bayram Veli Üniversitesi, Uzaktan Eğitim Uygulama ve Araştırma Merkezi, Ankara, Türkiye; esra.ozmen@hbv.edu.tr 


\section{Introduction}

It is important for communities to access, distribute and share information to improve their lifelong learning processes. Access to information and sharing of information can be realized through the Internet. But the Internet is not just about accessing information; it also meets the need for learning. Moreover, thanks to the Internet, education can be carried out independently of time and place. With the introduction of the Internet into our lives, education alternatives such as virtual classrooms, online trainings, and distance education have emerged and started to be preferred rather than face-to-face education. Distance education, which entered our lives with the development of the Internet, refers to the realization of the education with the use of communication technologies and mail services, although teachers and students are located in different locations (İşman, 2005, as cited in Altıparmak, Kurt \& Kapıdere, 2011). It is obvious that distance education has advantages such as active communication, benefiting from different educational institutions, independence from time and place. Çakır and Yalçın (2006) in their studies that they touched on the contribution of the Internet and intranet based virtual classroom system to education stated that whether the courses that can be given virtually are applied or theoretical may make a difference in terms of feasibility and effectiveness. In other words, it was mentioned that it is more difficult to give applied courses in virtual environment than theoretical ones. In another study investigating the effect of internet-supported education on e-learning attitudes, it was concluded that the developed web-supported learning environment positively increased the attitudes of pre-service teachers towards web-based education (Özgür \& Tosun, 2010). When we look at the studies on the use of the Internet in education, it has been observed that the motivation, attitude and thoughts of both students and teachers were positive. Indeed, as it is mentioned in the study of Mellati \& Khademi (2018), the main issue and difficulty that teachers faced changed from looking for the best teaching method to the best teaching tool.

It can be said that the internet is used in many areas such as shopping, entertainment, information acquisition in our daily life apart from education. Baran and Ata (2013) concluded that university students use instant messaging services and social networking sites more than blogs, wikis, podcasts and video sharing sites, and students' skill levels are higher in these technologies. In social media, people convey their opinions on topics such as products, brands, people, institutions, events, etc., by sharing various posts. Tengilimoğlu, Parıltı and Yar (2015) investigated the level of use of social media in the choice of hospital and physician. As a result of the study, it was seen that social media is an effective tool in healthcare purchasing behavior. In a study investigating the effects of social media on consumer behavior, the effect of social media on the reasons of university students choosing Apple and Samsung branded products was examined. As a result of the study, it was seen that Samsung and Apple users made consumption preferences by using social media, however the reasons for using social media were different (Ylldız, 2014). When we look at social media studies, it is seen that individuals increase their skill levels on a topic, express their opinions clearly, and exchange information about a particular product, institution or brand.

The necessity of using the social media used in all areas of life for educational purposes in order to improve society's lifelong learning processes should also be considered. In their study, Vural and Bat (2010) aimed to determine the social media habits of the students and to reveal some evaluation results. As a result of the data obtained, it was concluded that while the internet was mostly used to exchange information among students, social networks were mostly used to spend time. In the study by Kang and Zhang (2020), it is expressed that the use of forum-based online teaching outside of course hours in higher education effectively increase students' learning levels 
and motivation. Güneş (2016) examined the place of social networks in the context of social change, technology and education. As a result of the study, it has been seen that the identity of individuals in society and the society itself are important in the integration of social networks into education. For this reason, the necessity of studies on the integration of social networks into education has been mentioned. In the study, in which researches on the use of social networks such as Facebook, Twitter and Flickr in education processes were discussed, it was concluded that social media was effective in enhancing student-student, student-content and teacher-student interaction, and using and developing research, questioning and problem solving skills (Gülbahar, Kalelioğlu \& Madran, 2010). Within the scope of the studies examined, it was understood that social change was positively affected in integrating social networks into education, and it helped individuals find solutions to the problems they faced.

Examining the opinions of school administrators and teachers regarding the use of social media and tools in education, Menteșe (2013) reached the opinions such that the use of social media and tools in education increased the degree of learning of students and increased motivation. However, it is also concluded that social media environments and tools were different for each course, unsuitable for students of all levels, and they are effective in students with high internal motivation. In a study examining the relationship between university students 'social media addiction and their use of social media for educational purposes, a positive relationship was found between students' Facebook addictions and their educational uses. It has been observed that female students use Facebook for educational purposes higher than male students (Yllmazsoy \& Kahraman, 2017). It is understood that there may be a difference in the level of learning in terms of both course and demographic factors in the studies conducted for learning in social media. In addition, it is seen that social media environments are effective on students' motivation and success.

Within the scope of their study to identify the potential and obstacles in the use of social media for teaching in higher education, Manca and Ranieri (2016) evaluated tools retrieving and archiving content materials (blogs, wikis) for social networking sites (Twitter, Facebook), professional and academic networking services (LinkedIn, ResearchGate and Academia.edu), course writing and group work (podcast, YouTube and Vimeo, SlideShare). As a result, it was seen that academicians do not tend to integrate these tools into their practices for various reasons such as cultural resistance, pedagogical issues or institutional restrictions. In addition, it has been observed that there are differences among academicians in the way they use or perceive social media, mostly depending on the teaching discipline. In a study examining the inclusion of social media in higher education, students found it useful to include social media in their learning and regarded it as a complementary tool rather than a dominant teaching methodology. Students stated that social media improved their learning experiences (Cooke, 2017). A study was carried out on participatory learning and teaching practices in secondary education and it was proposed to integrate digital citizenship dimensions and a social media supported curriculum. (Gleason and Von Gillern, 2018). Shen (2020) stated that WeChat social media application, which is the most popular in China, is helpful in medical education. It was also stated that the use of WeChat application in education has improved teaching activities, enhanced student-centered communication, and increased students' satisfaction. When we look at the studies that use social media tools as the basis in the education system, it is observed that education levels of students increase and their motivation improve in the social media environments that the students think to be more interactive than traditional methods. 
Within the scope of this study, as a result of supporting the formal undergraduate courses with social media (Instagram) sharing, the satisfaction levels of the students were examined. Posts were shared via the Instagram application, which is one of the top three social media applications used by university students (İnce and Koçak, 2017). In addition, when social media tools were compared in terms of posts types used in the the study, it was decided that the Instagram application was the most appropriate one. In the study, 2nd and 3rd grade students of Management Information Systems department were considered as samples. The study was conducted with the participation of 180 students who took Decision Support Systems (DSS) or Introduction to Algorithm and Programming courses. In this context, answers to the following research questions were sought.

- On the levels of student attitudes towards the quality of the posts shared for learning purposes via Instagram,

- Is there a significant difference between male and female students?

- Is there any significant difference between the students taking the DSS and Algorithm course?

- Is there a significant difference in terms of the education period of the students?

- Is there a significant difference in terms of students' use of Instagram?

- On the levels of student attitudes towards the type and purpose of the posts shared for learning purposes on Instagram,

- Is there a significant difference between the groups in terms of gender?

$\circ$ Is there a significant difference between the students taking the DSS and Algorithm course?

- Is there a statistically significant difference between the groups in terms of the education period of the students?

$\circ$ Is there a significant difference between groups in terms of students' use of Instagram?

- Do Instagram posts for educational purposes,

- Have an impact on students' level of interest in the lesson?

- Have an impact on the learning process of students?

○ Have an impact on students' motivation levels and exam preparation processes?

\section{Methodology}

Within the scope of the study, students who continued their undergraduate education at Management Information Systems (MIS) department were provided with social media (Instagram) support in two courses where they received face-to-face education. The data were collected from these courses offered in the 2018-2019 Academic Year Spring Semester. The aforementioned courses are Introduction to Algorithms and Programming of 2nd grade and Decision Support System of 3rd class belonged to the department of the MIS. Students can take these courses separately or take two courses together in the same semester. In terms of the Introduction to Algorithms and Programming course objectives, students are expected to solve a problem in a logical way. At the end of the Decision Support Systems course, students are expected to find the optimum selection among the alternatives by using the qualifications for a decision problem and complete the decision making process. While for Introduction to Algorithms and Programming course, students were given practice by teaching both method and tool, in the Decision Support Systems course, only the method is taught and put into practice assuming that the tool used is known by students. 
In order to support the courses, various posts with various formats were shared on the Instagram account. The posts were designed as a result of the observations and opinions of the instructor giving the course and were presented to the students both via Instagram application and the Course Information System. Explanations about these shares are given below.

Live Broadcast: These are the activities where the instructor broadcasts live on a particular subject (reading exam papers, interpreting the answers given, lecturing, answering questions before the exam, introducing related conferences, etc.)

Lecturing: Each step of the subject is prepared and shared as a photo frame in the post in this scope. This activity is generally held two days after the lecture.

Question-Answer Hours: It is an event that allows students to ask questions about the course in a certain time interval in the near term to the midterm or final exams. In these activities, questions are answered quickly and additional posts are shared according to the frequency of the questions.

Mini Surveys: In the issues such as the announcements of the exam results, the degree of difficulty of the exam and the expectations of posts, mini-surveys of "yes / no" format are organized and the survey results are also published. Sharing continues according to the survey results. This event is shared as Instagram story.

Opportunities to provide opinions: Students are provided with an environment where they can write comments about situations such as course processing, difficulty level of exams, expectations about the course, sharing expectations of Instagram. Some of these comments are also shared. This event is shared as Instagram story.

Example questions: These are activities where sample exam questions are posted on Instagram and comments, likes or referrals are made according to the answers given.

Example exam question: These are the studies conducted on what kind of questions students will encounter in the exam. As in the example questions, the posts are updated according to the comments, likes or directions.

Greetings: These are greeting posts sent to the students on national and religious holidays, in the victories (national team victories etc.,) and on important days.

Announcement of Honor Students: These are the activities where only the names of the students who get a certain score in the exams are shared as Instagram story.

Tips on topics: These are activities in which posts are made in the form of clues on subjects that are thought to be confused or difficult to remember.

Social Activities: These are posts of the activities such as canteen meetings, seminars and conference participation with students.

These activities were gathered under 4 title according to the expert opinion in terms of teaching and presented in Table 1. 
Table 1. Classification of Instagram posts in terms of instruction

\begin{tabular}{|l|l|l|l|}
\hline $\begin{array}{l}\text { Posts For the Learning } \\
\text { Process }\end{array}$ & $\begin{array}{l}\text { Posts for Assessment and } \\
\text { Evaluation }\end{array}$ & $\begin{array}{l}\text { Question-Answer } \\
\text { Activities }\end{array}$ & Social Posts \\
\hline Tips on topics & $\begin{array}{l}\text { Announcement of Honor } \\
\text { Students } \\
\text { Example questions }\end{array}$ & $\begin{array}{l}\text { Question-answer } \\
\text { hours } \\
\text { Live broadcast }\end{array}$ & $\begin{array}{l}\text { Greetings } \\
\text { broadcast }\end{array}$ \\
$\begin{array}{l}\text { Live broadcast } \\
\text { Question-answer hours }\end{array}$ & $\begin{array}{l}\text { Example exam question } \\
\text { Mini Surveys } \\
\text { Opportunities for feedback }\end{array}$ & & \\
\hline
\end{tabular}

\subsection{Population and Sample of the Research}

The study was carried out with 180 students out of a total of 246 students who took the courses. The students participating in the study were asked about their gender, their education period in the MIS department, the status of taking the DSS and / or Algorithm and Programming course, their Instagram account use, and their follow-up status of the course. The distribution of gender data of the participants is presented in Table 2.

Table 2. Gender distributions of participants

\begin{tabular}{lll}
\hline Gender Groups & $\mathbf{N}$ & $\mathbf{\%}$ \\
\hline Female & 78 & 43.3 \\
Male & 102 & 56.7 \\
Total & 180 & 100.0 \\
\hline
\end{tabular}

When Table 2 is examined, it is seen that $43.3 \%$ of the participants are female students $(\mathrm{N}=78)$ and $56.7 \%$ of them are male students $(\mathrm{N}=102)$. The distribution of the education period of the students participating in the study in the MIS department is presented in Table 3.

Table 3. Education period of participants in the department of mis

\begin{tabular}{lll}
\hline Education periods (years) & $\mathbf{N}$ & $\mathbf{\%}$ \\
\hline 1 & 5 & 2.8 \\
2 & 70 & 38.9 \\
3 & 65 & 36.1 \\
4 & 24 & 13.3 \\
$5+$ & 16 & 8.9 \\
Total & 180 & 100.0 \\
\hline
\end{tabular}

When Table 3 is examined, it is seen that $2.8 \%$ of the participants are students in the MIS department for 1 year $(\mathrm{N}=5), 38.9 \%$ for 2 years $(\mathrm{N}=70), 36.1 \%$ for 3 years $(\mathrm{N}=65), 13,3 \%$ for 4 years and $8.9 \%$ of them for 5 years and more $(\mathrm{N}=16)$

The distribution of the participants' taking Introduction to Algorithms and Programming course for 2nd graders, DSS for 3rd graders or taking both of the courses is presented in Table 4 .

Table 4. Distribution of the courses taken by the participants

\begin{tabular}{lll}
\hline Courses & $\mathbf{N}$ & $\mathbf{\%}$ \\
\hline Decision Support Systems & 74 & 41.1 \\
Introduction to Algorithm and & 96 & 53.3 \\
Programming & & \\
DSS - Algorithm & 10 & 5.6 \\
Total & 180 & 100.0 \\
\hline
\end{tabular}


When Table 4 is examined, it is seen that $41.1 \%$ of the participants took the DSS course $(\mathrm{N}=74)$, $53.3 \%$ took the Algorithms and Programming course $(\mathrm{N}=96)$ and 5.6\% took both courses together. $(\mathrm{N}=10)$

Participants' use of Instagram accounts and how often they use them are presented in Table 5.

Table 5. Participants' use of Instagram

\begin{tabular}{lll}
\hline Using Instagram Account & $\mathbf{N}$ & $\mathbf{\%}$ \\
\hline I dont use & 13 & 7.2 \\
I occasionally use it & 32 & 17.8 \\
I use it every day & 57 & 31.7 \\
I always use it & 78 & 43.3 \\
Total & 180 & 100.0 \\
\hline
\end{tabular}

When Table 5 is examined, it is observed that $7.2 \%$ of the participants do not use Instagram $(\mathrm{N}=$ 13), $17.8 \%$ use the Instagram application occasionally $(\mathrm{N}=32), 31.7 \%$ use it every day $(\mathrm{N}=57)$ and $43.3 \%$ of them use Instagram application at all times $(\mathrm{N}=78)$.

The following status of Instagram account of the course by the participants is presented in Table 6.

Table 6. Participants' follow-up Instagram account of the course

\begin{tabular}{lll}
\hline Follow-up status of the course & $\mathbf{N}$ & $\mathbf{\%}$ \\
\hline Yes & 165 & 91.7 \\
No & 15 & 8.3 \\
Total & 180 & 100.0 \\
\hline
\end{tabular}

When Table 6. is examined, it is seen that $91.7 \%$ of the participants follow the course's Instagram account $(\mathrm{N}=165)$ and $8.3 \%$ do not follow $(\mathrm{N}=15)$.

\subsection{Data Collection Tools}

In this study, the questionnaire named as "Student Satisfaction Level Determination Scale in Social Media Assisted Education" and given in Appendix A were used, and data were collected from 180 students. Within the scope of the mixed research study, both qualitative and quantitative data were collected simultaneously. The data were collected in the spring semester of the 2018-2019 Academic Year. This data collection instrument developed by inspiring from the study conducted by Karaman (2010) examining the effect of audio and written feedback on student satisfaction and achievement levels. The questionnaire consists of four main sections. While the first section contains questions about the demographic information of the participants, the second section consists of 7-point Likert-type questions that examine the quality information of the posts. The questions in this section composed of the students' statements such as self-development, seeing their deficiencies, facilitating the learning process, increasing interest in the course, feeling good, communicating with the instructor, finding a place in the course, finding the posts satisfactory and beneficial, and finally supporting the other courses with Instagram application. In the fourth part, there are 3 open-ended questions for students to get their ideas about sharing and supporting the course through Instagram. 


\subsection{Data Analysis}

Quantitative data obtained from the participants were analyzed in the SPSS software. The data were analyzed by independent sample t-test, which compares the averages of two different sample groups, and find out whether there is a statistically significant difference between them. In addition, one-way ANOVA test method, consisting of dependent and independent variables and questioning whether there is a statistically significant difference compared to the averages in the dependent variable, was used (Ak, 2014). In the analysis of qualitative data, NVivo software was used and a descriptive analysis based on the arrangement and interpretation of the findings, aimed at classifying the data according to the conceptual framework and themes, was made (Sözbilir, 2009).

\subsection{The Role of the Researcher}

Within the scope of the study, the role of the researchers are; to follow the lectures, to make observations during the lecture, to assist the lecture, to design and publish the posts for the Instagram page, to create a questionnaire, to collect the data, and to analyze and interpret the data.

\subsection{Validity and Reliability}

The importance of the study in terms of validity and reliability is that the current sources have been reached in the literature review and the quantitative data is supported with the qualitative data, and validity and reliability tests have also been performed on the scales previously.

\section{Results}

Results obtained from the independent sample t test analysis conducted to determine whether there is a gender-based difference in student attitudes towards the quality of the posts made in the courses supported by Instagram are presented in Table 7.

Table 7. The differences between the quality attitude levels of the posts on Instagram between male and female students

\begin{tabular}{|c|c|c|c|c|c|c|c|}
\hline Variable & Group & $\mathbf{N}$ & $\mathbf{X}$ & SS & $\mathbf{t}$ & df & $\mathbf{P}$ \\
\hline \multirow[t]{2}{*}{ It was useful } & Female & 75 & 5.68 & 2.28 & \multirow{2}{*}{.22} & \multirow{2}{*}{169} & \multirow{2}{*}{.82} \\
\hline & Male & 96 & 5.60 & 2.15 & & & \\
\hline \multirow{2}{*}{ It was detailed } & Female & 75 & 5.51 & 1.98 & \multirow[b]{2}{*}{.99} & \multirow[b]{2}{*}{169} & \multirow[b]{2}{*}{.33} \\
\hline & Male & 96 & 5.20 & 2.07 & & & \\
\hline \multirow{2}{*}{$\begin{array}{l}\text { It was } \\
\text { understandable }\end{array}$} & Female & 75 & 5.68 & 2.09 & \multirow[b]{2}{*}{.40} & \multirow[b]{2}{*}{169} & \multirow[b]{2}{*}{.69} \\
\hline & Male & 96 & 5.55 & 2.06 & & & \\
\hline \multirow{2}{*}{$\begin{array}{l}\text { It was } \\
\text { comprehensive }\end{array}$} & Female & 75 & 5.52 & 2.02 & \multirow[b]{2}{*}{.93} & \multirow[b]{2}{*}{169} & \multirow[b]{2}{*}{.35} \\
\hline & Male & 96 & 5.23 & 2.03 & & & \\
\hline \multirow[t]{2}{*}{ It was sincere } & Female & 75 & 5.76 & 2.20 & \multirow{2}{*}{.47} & \multirow{2}{*}{169} & \multirow{2}{*}{.64} \\
\hline & Male & 96 & 5.60 & 2.10 & & & \\
\hline \multirow[t]{2}{*}{ It reflected the truth } & Female & 75 & 5.72 & 2.20 & \multirow{2}{*}{.22} & \multirow{2}{*}{169} & \multirow{2}{*}{.82} \\
\hline & Male & 96 & 5.65 & 2.10 & & & \\
\hline \multirow[t]{2}{*}{ It was motivating } & Female & 75 & 5.75 & 2.10 & \multirow{2}{*}{.60} & \multirow{2}{*}{169} & \multirow{2}{*}{.55} \\
\hline & Male & 96 & 5.55 & 2.11 & & & \\
\hline \multirow{2}{*}{ It was exhilarating } & Female & 75 & 5.55 & 2.18 & \multirow{2}{*}{.19} & \multirow{2}{*}{169} & \multirow{2}{*}{.24} \\
\hline & Male & 96 & 5.15 & 2.21 & & & \\
\hline
\end{tabular}

When Table 7 is examined, according to the results of independent sample $t$ test, there was no statistically significant difference between the attitude levels of male and female students towards sharing quality. The data obtained as a result of the independent sample $t$ test analysis conducted to determine whether there is a gender-based difference in the average of the attitude levels of 
the students in the lessons supported by Instagram application, and the type and purpose of the posts are presented in Table 8.

Table 8. Differences between attitude levels towards the type and purpose of the posts shared on Instagram between male and female students

\begin{tabular}{|c|c|c|c|c|c|c|c|}
\hline Variable & Group & $\mathbf{N}$ & $\mathbf{X}$ & SS & $\mathbf{t}$ & df & $\mathbf{p}$ \\
\hline \multirow{2}{*}{ Instagram live broadcasts help me improve myself. } & Female & 74 & 5.19 & 1.80 & \multirow{2}{*}{.67} & \multirow{2}{*}{169} & \multirow{2}{*}{.51} \\
\hline & Male & 95 & 5.00 & 1.86 & & & \\
\hline \multirow{2}{*}{$\begin{array}{l}\text { Instagram storytelling and sharing tips help me improve } \\
\text { myself. }\end{array}$} & Female & 75 & 5.79 & 1.80 & \multirow{2}{*}{.98} & \multirow{2}{*}{169} & \multirow{2}{*}{.33} \\
\hline & Male & 96 & 5.50 & 1.98 & & & \\
\hline \multirow{2}{*}{$\begin{array}{l}\text { Question-and-answer hours on Instagram help me } \\
\text { improve myself. }\end{array}$} & Female & 75 & 5.77 & 1.83 & \multirow{2}{*}{1.10} & \multirow[b]{2}{*}{169} & \multirow{2}{*}{.27} \\
\hline & Male & 96 & 5.46 & 1.89 & & & \\
\hline \multirow{2}{*}{$\begin{array}{l}\text { Lecturing sharing on Instagram allowed me to see the } \\
\text { shortcomings in the study. }\end{array}$} & Female & 75 & 6.01 & 1.70 & \multirow{2}{*}{1.77} & \multirow{2}{*}{169} & \multirow{2}{*}{.08} \\
\hline & Male & 95 & 5.51 & 1.97 & & & \\
\hline \multirow{2}{*}{$\begin{array}{l}\text { The Q\&A hours on Instagram allowed me to see the } \\
\text { shortcomings in my work. }\end{array}$} & Female & 74 & 5.82 & 1.74 & \multirow[b]{2}{*}{1.48} & \multirow[b]{2}{*}{169} & \multirow[b]{2}{*}{.14} \\
\hline & Male & 96 & 5.40 & 1.97 & & & \\
\hline \multirow{2}{*}{$\begin{array}{l}\text { The posts of example questions / exam questions helped } \\
\text { me see the shortcomings in my work. }\end{array}$} & Female & 75 & 5.91 & 1.83 & & & \\
\hline & Male & 96 & 5.58 & 1.94 & 1.11 & 169 & .27 \\
\hline The answers I received to the questions I asked on & Female & 75 & 5.80 & 1.86 & & & \\
\hline Instagram had a positive effect on the learning process. & Male & 96 & 5.45 & 1.92 & 1.21 & 169 & .23 \\
\hline Instagram live broadcasts increased my interest in the & Female & 75 & 5.47 & 1.84 & & & \\
\hline course. & Male & 96 & 5.22 & 1.90 & .86 & 169 & .39 \\
\hline Instagram question and answer hours have increased my & Female & 74 & 5.82 & 1.72 & & & \\
\hline interest in the course. & Male & 94 & 5.28 & 1.96 & 1.90 & 169 & .06 \\
\hline The announcement of honor students on Instagram has & Female & 75 & 5.80 & 1.76 & & & \\
\hline increased my interest in the course. & Male & 96 & 5.08 & 2.09 & 9 & 169 & .02 \\
\hline Sharing, which creates an opportunity to express an & Female & 74 & 5.96 & 1.70 & & & \\
\hline $\begin{array}{l}\text { opinion on Instagram, increased my interest towards the } \\
\text { course. }\end{array}$ & Male & 95 & 5.58 & 1.87 & 1.37 & 169 & .17 \\
\hline & Female & 74 & 5.80 & 1.70 & & & \\
\hline Having greeting posts on Instagram & Male & 96 & 5.29 & 2.00 & 1.74 & 169 & .08 \\
\hline The announcement of honor students on Inst & Female & 75 & 5.61 & 1.75 & & & \\
\hline me feel good. & Male & 96 & 5.27 & 1.96 & 9 & 169 & .24 \\
\hline Having social activity posts on Instagram made me feel & Female & 75 & 5.79 & 1.77 & & & \\
\hline good. & Male & 96 & 5.40 & 1.89 & 1.38 & 169 & .17 \\
\hline Using Instagram as part of the lesson made me feel like I & Female & 75 & 5.93 & 1.72 & & & \\
\hline was in direct & Male & 96 & 5.55 & 1.93 & 4 & 169 & .18 \\
\hline I saw that I found myself in the lesson thanks to the & Female & 73 & 5.92 & 1.63 & & & \\
\hline sharing of opinions on Instagram. & Male & 95 & 5.41 & 1.96 & 1.79 & 169 & .08 \\
\hline Thanks to the mini questionnaire posts on Instagram, I & Female & 74 & 5.85 & 1.69 & & & \\
\hline saw that I found myself in the lesson. & Male & 96 & 5.31 & 1.93 & 1.91 & 169 & .06 \\
\hline I saw that I found myself in the class thanks to the live & Female & 75 & 5.61 & 1.82 & & & \\
\hline broadcasts on Instagram. & Male & 96 & 5.25 & 1.95 & 5 & 169 & 7 \\
\hline Thanks to questions and answers hours on Instagram, I & Female & 75 & 5.75 & 1.73 & & & \\
\hline saw that I found myself in the lesson. & Male & 96 & 5.30 & 1.94 & 1.56 & 169 & .12 \\
\hline The announcement of honor students on Instagram, I saw & Female & 75 & 5.71 & 1.76 & & & \\
\hline that I found myself in the lesson. & Male & 96 & 5.16 & 1.94 & 1.91 & 169 & .06 \\
\hline & Female & 74 & 5.88 & 1.81 & & & \\
\hline Other lessons should also be supported using Instagram. & Male & 96 & 5.51 & 1.96 & 1.26 & 169 & .21 \\
\hline I found the comments on Instagram posts useful in & Female & 75 & 5.88 & 1.76 & & 169 & 08 \\
\hline general. & Male & 95 & 5.37 & 1.97 & 6 & 169 & .08 \\
\hline & Female & 73 & 5.77 & 1.84 & & & \\
\hline Comments on Instagram posts were satisfactory. & Male & 96 & 5.16 & 1.96 & 2.06 & 169 & .04 \\
\hline & Female & 72 & 5.76 & 1.76 & & & \\
\hline I learned new things thanks to Instagram $\mathrm{p}$ & Male & 95 & 5.51 & 1.93 & .89 & 169 & .38 \\
\hline
\end{tabular}

When Table 8 is examined, according to the results of independent sample t test, the attitude levels of female and male students towards the type and purpose of the posts made on Instagram are examined. Accordingly, female students stated that the announcement of honors students increased the interest in the course and found the comments on the posts satisfactory $(\mathrm{p}<0.05)$. They stated that female students shared more of the deficiencies in the work of Instagram lectures 
than male students and that their Instagram question and answer hours increased their interest towards the course $(\mathrm{p}<0.10)$. According to the result of analyzing the data on students' finding a place for themselves in the course, it is seen that female students have more positive attitude in terms of greetings posts, comments, mini-questionnaires and announcement posts of honor students than male students $(\mathrm{p}<0.10)$. Female students found the comments on Instagram posts generally more useful than male students $(p<0.10)$.

In the quality knowledge attitudes of the posts made in courses supported by Instagram application, independent sample t test analysis results to determine whether there is a difference between students who have DSS course and students who take the Algorithm course are presented in Table 9.

Table 9. The differences between the attitude levels of the students taking DSS or Algorithm course about the quality of the posts made on Instagram

\begin{tabular}{|c|c|c|c|c|c|c|c|}
\hline Variable & Group & $\mathbf{N}$ & $\mathbf{X}$ & SS & $\mathbf{t}$ & df & $\mathbf{p}$ \\
\hline \multirow[t]{2}{*}{ It was useful } & DSS & 72 & 5.63 & 2.33 & \multirow{2}{*}{-.18} & \multirow{2}{*}{160} & \multirow{2}{*}{.85} \\
\hline & Algorithm & 90 & 5.69 & 2.08 & & & \\
\hline \multirow[t]{2}{*}{ It was detailed } & DSS & 72 & 5.31 & 1.19 & \multirow{2}{*}{-.19} & \multirow{2}{*}{160} & \multirow{2}{*}{.35} \\
\hline & Algorithm & 90 & 5.37 & 1.89 & & & \\
\hline \multirow{2}{*}{$\begin{array}{l}\text { It was } \\
\text { understandable }\end{array}$} & DSS & 72 & 5.75 & 2.12 & \multirow[b]{2}{*}{.70} & \multirow[b]{2}{*}{160} & \multirow[b]{2}{*}{.49} \\
\hline & Algorithm & 90 & 5.52 & 2.01 & & & \\
\hline \multirow{2}{*}{$\begin{array}{l}\text { It was } \\
\text { comprehensive }\end{array}$} & DSS & 72 & 5.40 & 2.12 & \multirow[b]{2}{*}{.12} & \multirow[b]{2}{*}{160} & \multirow[b]{2}{*}{.91} \\
\hline & Algorithm & 90 & 5.37 & 1.89 & & & \\
\hline \multirow[t]{2}{*}{ It was sincere } & DSS & 72 & 5.67 & 2.28 & \multirow{2}{*}{-.13} & \multirow{2}{*}{160} & \multirow{2}{*}{.90} \\
\hline & Algorithm & 90 & 5.71 & 2.02 & & & \\
\hline \multirow{2}{*}{ It reflected the truth } & DSS & 72 & 5.68 & 2.26 & \multirow{2}{*}{-.06} & \multirow{2}{*}{160} & \multirow{2}{*}{.95} \\
\hline & Algorithm & 90 & 5.70 & 2.05 & & & \\
\hline \multirow[t]{2}{*}{ It was motivating } & DSS & 72 & 5.69 & 2.21 & \multirow{2}{*}{.15} & \multirow{2}{*}{160} & \multirow{2}{*}{.88} \\
\hline & Algorithm & 90 & 5.64 & 2.01 & & & \\
\hline \multirow{2}{*}{ It was exhilarating } & DSS & 72 & 5.38 & 2.36 & \multirow{2}{*}{.12} & \multirow{2}{*}{160} & \multirow{2}{*}{.90} \\
\hline & Algorithm & 90 & 5.33 & 2.03 & & & \\
\hline
\end{tabular}

When Table 9 is examined, according to the results of independent sample $t$ test, there is no statistically significant difference between the students taking the DSS course and the attitude levels towards the sharing quality of the students taking the Algorithm course.

In the attitude levels towards the type and purpose of the posts shared in the courses supported by the Instagram application, the data obtained as a result of the independent sample $t$ test analysis conducted to determine whether there is a difference between the students who take the DSS course and the students who take the Algorithm course are presented in Table 10. 
Table 10. Differences between the attitude levels of students taking DSS course and students taking Algorithm course towards the type and purpose of the posts shared on Instagram

\begin{tabular}{|c|c|c|c|c|c|c|c|}
\hline Variable & Group & $\mathbf{N}$ & $\mathbf{X}$ & SS & $\mathbf{t}$ & df & $\mathbf{p}$ \\
\hline \multirow{2}{*}{ Instagram live broadcasts help me improve myself. } & DSS & 72 & 5.33 & 1.88 & \multirow{2}{*}{1.35} & \multirow{2}{*}{160} & \multirow{2}{*}{.19} \\
\hline & Algorithm & 90 & 4.94 & 1.77 & & & \\
\hline \multirow{2}{*}{$\begin{array}{l}\text { Instagram storytelling and sharing tips help me } \\
\text { improve myself. }\end{array}$} & DSS & 72 & 5.79 & 1.94 & \multirow{2}{*}{.86} & \multirow{2}{*}{160} & \multirow{2}{*}{.39} \\
\hline & Algorithm & 90 & 5.53 & 1.84 & & & \\
\hline \multirow{2}{*}{$\begin{array}{l}\text { Question-and-answer hours on Instagram help me } \\
\text { improve myself. }\end{array}$} & DSS & 72 & 5.81 & 1.90 & \multirow{2}{*}{1.09} & \multirow[b]{2}{*}{160} & \multirow{2}{*}{.28} \\
\hline & Algorithm & 90 & 5.49 & 1.79 & & & \\
\hline \multirow{2}{*}{$\begin{array}{l}\text { Lecturing sharing on Instagram allowed me to see } \\
\text { the shortcomings in the study. }\end{array}$} & $\mathrm{D} s$ & 72 & 5.99 & 1.84 & \multirow[b]{2}{*}{1.41} & \multirow[b]{2}{*}{160} & \multirow{2}{*}{16} \\
\hline & Algorithm & 90 & 5.58 & 1.82 & & & \\
\hline \multirow{2}{*}{$\begin{array}{l}\text { The Q\&A hours on Instagram allowed me to see the } \\
\text { shortcomings in my work. }\end{array}$} & DSS & 72 & 5.82 & 1.86 & \multirow{2}{*}{1.38} & \multirow{2}{*}{160} & \multirow{2}{*}{17} \\
\hline & Algorithm & 90 & 5.42 & 1.82 & & & \\
\hline \multirow{2}{*}{$\begin{array}{l}\text { The posts of example questions / exam questions } \\
\text { helped me see the shortcomings in my work. }\end{array}$} & DSS & 72 & 5.96 & 1.92 & & & \\
\hline & Algorithm & 90 & 5.56 & 1.82 & .37 & 160 & {$[7$} \\
\hline The answers I received to the questions I asked on & DSS & 72 & 5.76 & 1.90 & & & \\
\hline $\begin{array}{l}\text { Instagram had a positive effect on the learning } \\
\text { process. }\end{array}$ & Algorithm & 90 & 5.50 & 1.86 & .89 & 160 & .38 \\
\hline Instagram live broadcasts increased my interest in & $\mathrm{Ds}$ & 72 & 5.50 & 1.91 & & & \\
\hline & thm & 90 & 5.21 & 1.81 & .94 & 160 & .33 \\
\hline stion and answer hours have & DSS & 72 & 5.70 & 1.90 & & & \\
\hline nterest in the co & Algorithm & 90 & 5.41 & 1.81 & .99 & 160 & 2 \\
\hline tis on mintagra & Ds & 72 & 5.64 & 1.97 & 26 & 160 & 21 \\
\hline in & Algor & 90 & 5.26 & 1.89 & 1.26 & 160 & .21 \\
\hline which creates an opportunity to express an & DSS & 72 & 6.01 & 1.84 & & & \\
\hline $\begin{array}{l}\text { opinion on Instagram, increased my interest } \\
\text { towards the course. }\end{array}$ & ithm & 90 & 5.58 & 1.70 & 1.54 & 160 & .13 \\
\hline sts on Instagram made me feel & & 72 & 5.74 & 1.84 & & & \\
\hline gc & $\mathrm{Al}$ & 90 & 5.39 & 1.83 & .18 & 160 & 24 \\
\hline ent of honor students on Instagram & DS & 72 & 5.65 & 1.85 & $126+2+2>0$ & 60 & 21 \\
\hline & Algorithm & 90 & 5.29 & 1.80 & 1.20 & 100 & .21 \\
\hline gram made me & Ds & 72 & 5.88 & 1.85 & & 160 & \\
\hline & $\mathrm{Al}$ & 90 & 5.37 & 1.76 & 1.19 & 100 & $\delta$ \\
\hline $\mathrm{n}$ made me feel & DS & 72 & 6.01 & 1.84 & 180 & 160 & 08 \\
\hline ict with the instructor. & Algorithm & 90 & 5.50 & 1.78 & & 160 & .08 \\
\hline I saw that I found myself in the lesson thanks to the & DSS & 72 & 5.94 & 1.83 & & 160 & 6 \\
\hline & $\mathrm{Al}$ & 90 & 5.41 & 1.75 & $1.8 /$ & 160 & 0 \\
\hline osts on & DS & 72 & 5.82 & 1.82 & & 60 & 10 \\
\hline If in the lesson. & Algorithm & 90 & 5.35 & 1.81 & & 160 & 10 \\
\hline I saw that I found myself in the class thanks to the & DSS & 72 & 5.69 & 1.89 & & & \\
\hline or on In & Algol & 90 & 5.19 & 1.85 & & 160 & 99 \\
\hline Tha & DS & 72 & 5.78 & 1.89 & & & \\
\hline Inst & $\mathrm{Al}$ & 90 & 5.29 & 1.78 & 1.0 & 160 & 19 \\
\hline ouncement of honor students on Instagram, & DSS & 72 & 5.64 & 1.83 & & & 0 \\
\hline I saw that I found myself in the lesson. & Algorithm & 90 & 5.27 & 1.83 & & & \\
\hline Other lessons should also be supported using & DS & 72 & 5.97 & 1.96 & & 160 & 10 \\
\hline Instag & & 90 & 5.48 & 1.78 & & 160 & .10 \\
\hline I found the comments on Instagram posts useful in & DSS & 72 & 5.86 & 1.94 & & & 1 \\
\hline general. & Algorithm & 90 & 5.43 & 1.78 & 8 & 0 & 4 \\
\hline satisfactor & DSS & 72 & 5.65 & 1.99 & 123 & 160 & 22 \\
\hline Sallsidetury. & Algo & 90 & 5.28 & 1.83 & & 100 & \\
\hline I learned new things thanks to Instagram po & & 72 & 5.87 & 1.87 & 1.46 & 160 & .15 \\
\hline & Algorithm & 90 & 5.44 & 1.80 & & & \\
\hline
\end{tabular}

When Table 10 is examined, according to the results of the independent sample t test, the attitudes levels of the students who took the DSS course and the students who took the Algorithm course were examined. Accordingly, students taking the DSS course stated that the sharing of social activities made them feel good and that using Instagram as part of the course felt like they were 
in direct contact with the instructor $(\mathrm{p}<0.10)$. In addition, students who took DSS courses reported that they found a place in the lesson thanks to their opinion sharing, mini surveys, live broadcasts and question and answer hours. $(\mathrm{p}<0.10)$. In addition, students taking the DSS course expressed their opinion that other courses should be supported by using Instagram. $(\mathrm{p}<0.10)$. One-way analysis of variance was carried out to determine whether there is a difference between the attitude levels towards the quality information of the shares made in the courses supported by the Instagram application and the education period of 169 students and the results of the analysis are presented in Table 11.

Table 11. One-way analysis of variance results regarding the difference between the variable of education period and quality attitude levels of the posts

\begin{tabular}{|c|c|c|c|c|c|c|c|}
\hline & \multicolumn{2}{|c|}{$\begin{array}{l}\text { Between groups } \\
\text { (df=5) }\end{array}$} & \multicolumn{2}{|c|}{$\begin{array}{l}\text { Within groups } \\
\text { (df=164) }\end{array}$} & \multirow{2}{*}{$\begin{array}{l}\begin{array}{l}\text { Total } \\
\text { (df=168) }\end{array} \\
\text { Mean of } \\
\text { squares } \\
\end{array}$} & \multirow[t]{2}{*}{$\mathbf{F}$} & \multirow[t]{2}{*}{$\mathbf{p}$} \\
\hline & $\begin{array}{c}\text { Sum of } \\
\text { Squares }\end{array}$ & $\begin{array}{l}\text { Mean of } \\
\text { squares }\end{array}$ & $\begin{array}{l}\text { Sum of } \\
\text { Squares }\end{array}$ & $\begin{array}{l}\text { Mean of } \\
\text { square }\end{array}$ & & & \\
\hline It was useful & 11.07 & 2.77 & 812.18 & 4.95 & 823.25 & .56 & .69 \\
\hline It was detailed & 9.62 & 2.41 & 689.82 & 4.21 & 699.44 & .57 & .68 \\
\hline Itwasunderstandable & 8.59 & 2.15 & 714.05 & 4.35 & 722.64 & .49 & .74 \\
\hline Itwascomprehensive & 17.15 & 4.29 & 679.55 & 4.14 & 696.70 & 1.04 & .39 \\
\hline It was sincere & 10,01 & 2.50 & 765.77 & 4.67 & 775.78 & .54 & .71 \\
\hline It reflected the truth & 16.56 & 4.14 & 762.55 & 4.65 & 779.10 & .89 & .47 \\
\hline It was motivating & 8.26 & 2.06 & 743 & 4.53 & 751.26 & .46 & .77 \\
\hline It was exhilarating & 9.07 & 2.27 & 809.31 & 4.94 & 818.38 & .46 & .77 \\
\hline
\end{tabular}

According to Table 11, one-way analysis of variance was conducted to determine whether there is a statistical difference between the attitude levels of the posts in the courses supported by the Instagram application and the education period of the students and it was observed that there was no significant difference between the mean scores of the groups. In other words, it has been observed that the duration of education does not have an effect on the attitude levels of students regarding the quality of their Instagram posts. One-way analysis of variance was conducted to determine whether there is a difference between the attitude levels of the knowledge shared in the courses supported by the Instagram application and the status of 171 students using the Instagram application, and the data obtained as a result of the analysis are presented in Table 12.

Table 12. One-way analysis of variance results regarding the difference between Instagram usage variable and the quality attitude levels of the posts

\begin{tabular}{|c|c|c|c|c|c|c|c|}
\hline & \multicolumn{2}{|c|}{ Between groups $(\mathrm{df}=3)$} & \multicolumn{2}{|c|}{ Within groups $(\mathrm{df}=167)$} & \multirow{2}{*}{$\begin{array}{l}\begin{array}{l}\text { Total } \\
(\mathrm{df}=170)\end{array} \\
\text { Mean of } \\
\text { squares } \\
\end{array}$} & \multirow[t]{2}{*}{$\mathbf{F}$} & \multirow[t]{2}{*}{$\mathbf{p}$} \\
\hline & $\begin{array}{l}\text { Sum of } \\
\text { Squares }\end{array}$ & $\begin{array}{l}\text { Mean of } \\
\text { squares }\end{array}$ & $\begin{array}{l}\text { Sum of } \\
\text { Squares }\end{array}$ & $\begin{array}{l}\text { Mean of } \\
\text { squares }\end{array}$ & & & \\
\hline It was useful & 6.34 & 2.11 & 817.19 & 4.89 & 823.52 & .43 & .73 \\
\hline It was detailed & 3.65 & 1.22 & 696.36 & 4.17 & 700 & .29 & .83 \\
\hline Itwasunderstandable & 5.48 & 1.83 & 719.27 & 4.31 & 724.75 & .42 & .74 \\
\hline Itwascomprehensive & 9.82 & 3.27 & 687.42 & 4.12 & 697.24 & .80 & .50 \\
\hline It was sincere & 6.94 & 2.31 & 770.72 & 4.62 & 777.66 & .50 & .68 \\
\hline It reflected the truth & 6.25 & 2.08 & 773.06 & 4.63 & 779.31 & .45 & .72 \\
\hline It was motivating & 10.55 & 3.52 & 740.97 & 4.44 & 751.52 & .79 & .50 \\
\hline It was exhilarating & 25.68 & 8.56 & 795.64 & 4.76 & 821.31 & 1.80 & .15 \\
\hline
\end{tabular}


When Table 12 is considered, one-way analysis of variance was conducted to determine whether there is a difference between the attitude levels of the knowledge in the courses supported by the Instagram application and the students' use of Instagram and it was observed that there was no significant difference between the groups' mean scores. In other words, the use of Instagram has no effect on the attitude levels of students towards the quality of their Instagram posts. One-way analysis of variance was carried out to determine whether there is a difference between the purpose and type of attitudes shared in the courses supported by the Instagram application and the education period of 169 students and the data obtained as a result of the analysis are presented in Table 13.

Table 13. One-way analysis of variance results related to the difference between the education period and the level of attitude towards the type and purpose of the posts.

\begin{tabular}{|c|c|c|c|c|c|c|c|}
\hline & \multicolumn{2}{|c|}{ Between groups $(\mathrm{df}=4)$} & \multicolumn{2}{|c|}{ Within groups $(\mathrm{df}=164)$} & \multirow{2}{*}{$\begin{array}{l}\begin{array}{l}\text { Total } \\
(\mathrm{df}=168)\end{array} \\
\text { Mean of } \\
\text { squares }\end{array}$} & \multirow[t]{2}{*}{$\mathbf{F}$} & \multirow[t]{2}{*}{$\mathbf{p}$} \\
\hline & $\begin{array}{l}\text { Sum of } \\
\text { Squares }\end{array}$ & $\begin{array}{l}\text { Mean of } \\
\text { squares }\end{array}$ & $\begin{array}{l}\text { Sum of } \\
\text { Squares }\end{array}$ & $\begin{array}{l}\text { Mean of } \\
\text { squares }\end{array}$ & & & \\
\hline S2.1 & 15.71 & 3.93 & 545.43 & 3.37 & 561.14 & 1.17 & .33 \\
\hline $\mathrm{S} 2.2$ & 5.45 & 1.36 & 610.32 & 3.72 & 615.76 & .37 & .83 \\
\hline S2.3 & 5.80 & 1.45 & 585.03 & 3.57 & 590.83 & .41 & .80 \\
\hline S2.4 & 4.03 & 1.01 & 585.37 & 3.59 & 589.41 & .28 & .89 \\
\hline S2.5 & 6.49 & 1.62 & 538.17 & 3.60 & 592.66 & .45 & .77 \\
\hline S2.6 & 4.22 & 1.05 & 603.26 & 3.68 & 607.48 & .29 & .89 \\
\hline S2.7 & 3.72 & .93 & 606.28 & 3.70 & 610 & .25 & .91 \\
\hline S2.8 & 8.13 & 2.03 & 587.64 & 3.58 & 595.78 & .57 & .69 \\
\hline S2.9 & 6.35 & 1.59 & 577.00 & 3.58 & 583.35 & .44 & .78 \\
\hline S2.10 & 11.63 & 2.91 & 650.81 & 3.97 & 662.44 & .73 & .57 \\
\hline S2.11 & 12.26 & 3.07 & 530.68 & 3.28 & 542.93 & .94 & .45 \\
\hline S2.12 & 6.73 & 1.68 & 593.22 & 3.64 & 599.95 & .46 & .76 \\
\hline S2.13 & 8.23 & 2.06 & 588.94 & 3.59 & 597.17 & .57 & .68 \\
\hline S2.14 & 11.13 & 2.78 & 566.34 & 3.45 & 577.47 & .81 & .52 \\
\hline S2.15 & 10.57 & 2.64 & 567.36 & 3.46 & 577.93 & .76 & .55 \\
\hline S2.16 & 11.72 & 2.93 & 550.87 & 3.42 & 562.58 & .86 & .49 \\
\hline S2.17 & 13.37 & 3.34 & 560.14 & 3.44 & 573.52 & .97 & .42 \\
\hline S2.18 & 20.45 & 5.11 & 588.72 & 3.59 & 609.17 & 1.42 & .23 \\
\hline S2.19 & 15.35 & 3.84 & 568.90 & 3.47 & 584.25 & 1.11 & .36 \\
\hline S2.20 & 15.50 & 3.87 & 583.14 & 3.56 & 598.64 & 1.09 & .36 \\
\hline $\mathrm{S} 2.21$ & 9.15 & 2.29 & 597.50 & 3.67 & 606.64 & .62 & .65 \\
\hline $\mathrm{S} 2.22$ & 6.12 & 1.53 & 594.17 & 3.65 & 600.28 & .42 & .79 \\
\hline S2.23 & 7.95 & 1.99 & 612.87 & 3.78 & 620.81 & .53 & .72 \\
\hline S2.24 & 3.49 & .87 & 569.69 & 3.56 & 573.18 & .25 & .91 \\
\hline
\end{tabular}

As in Table 13, one-way analysis of variance was conducted to determine whether there is a difference between the attitude levels towards the type and purpose of the shares in the courses supported by the Instagram application and the education period of the students, and it was observed that there was no significant difference between the groups' mean scores. That is, it has been observed that the duration of education does not have an effect on the attitude levels of students regarding the type and purpose of their Instagram posts.

One-way analysis of variance was carried out to determine whether there is a difference between the purpose and type of attitudes towards the type of posts shared on Instagram and the status of 171 students using Instagram and the data obtained as a result of the analysis are presented in Table 14. 
Table 14. One-way analysis of variance results related to the difference between Instagram usage variable and the type and purpose of the posts

\begin{tabular}{llllllll}
\hline & \multicolumn{2}{l}{$\begin{array}{l}\text { Between groups } \\
\text { (df=3) }\end{array}$} & $\begin{array}{l}\text { Within groups } \\
\text { (df=167) }\end{array}$ & Total (df=170) & F & p \\
\cline { 2 - 9 } & $\begin{array}{l}\text { Sum of } \\
\text { Squares }\end{array}$ & $\begin{array}{l}\text { Mean of } \\
\text { squares }\end{array}$ & $\begin{array}{l}\text { Sum of } \\
\text { Squares }\end{array}$ & $\begin{array}{l}\text { Mean of } \\
\text { squares }\end{array}$ & $\begin{array}{l}\text { Mean of } \\
\text { squares }\end{array}$ & & \\
\cline { 2 - 9 } & 16.77 & 5.59 & 546.07 & 3.31 & 562.84 & 1.69 & .17 \\
S2.1 & 9.27 & 3.09 & 606.78 & 3.63 & 616.05 & .85 & .47 \\
S2.2 & 3.90 & 1.30 & 587.26 & 3.52 & 591.16 & .37 & .78 \\
S2.3 & 4.85 & 1.62 & 584.70 & 3.52 & 589.55 & .46 & .71 \\
S2.4 & 4.06 & 1.35 & 591.29 & 3.56 & 595.35 & .38 & .77 \\
S2.5 & 5.72 & 1.91 & 602.36 & 3.61 & 608.08 & .53 & .66 \\
S2.6 & 8.55 & 2.85 & 604.41 & 3.62 & 612.96 & .79 & .50 \\
S2.7 & 6.62 & 2.21 & 591.04 & 3.54 & 597.66 & .62 & .60 \\
S2.8 & 10.22 & 3.41 & 575.73 & 3.51 & 585.95 & .97 & .41 \\
S2.9 & 10.53 & 3.51 & 652.43 & 3.91 & 662.96 & .90 & .44 \\
S2.10 & 7.26 & 2.42 & 536.80 & 3.25 & 544.06 & .74 & .53 \\
S2.11 & 7.01 & 2.34 & 593.46 & 3.58 & 600.48 & .65 & .58 \\
S2.12 & 4.43 & 1.48 & 593.25 & 3.55 & 597.68 & .42 & .74 \\
S2.13 & 4.32 & 1.11 & 570.15 & 3.50 & 573.47 & .32 & .81 \\
S2.14 & 4.99 & 1.66 & 572.98 & 3.43 & 577.98 & .49 & .69 \\
S2.15 & 5.01 & 1.67 & 573.52 & 3.43 & 578.53 & .49 & .69 \\
S2.16 & 6.25 & 2.08 & 556.87 & 3.40 & 563.12 & .61 & .61 \\
S2.17 & 6.12 & 2.04 & 568.01 & 3.42 & 574.12 & .60 & .62 \\
S2.18 & 4.58 & 1.53 & 606.77 & 3.63 & 611.35 & .42 & .74 \\
S2.19 & 6.35 & 2.12 & 580.40 & 3.48 & 586.75 & .61 & .61 \\
S2.20 & 6.71 & 2.24 & 594.25 & 3.56 & 600.96 & .63 & .60 \\
S2.21 & 6.38 & 2.13 & 603.18 & 3.63 & 609.55 & .59 & .63 \\
S2.22 & 1.36 & .45 & 601.64 & 3.62 & 602.99 & .13 & .95 \\
S2.23 & 5.22 & 1.74 & 617.95 & 3.75 & 623.17 & .47 & .71 \\
S2.24 & & & & & & & \\
\hline
\end{tabular}

When Table 14 is considered, one-way analysis of variance was conducted to determine whether there is a difference between the type and purpose of the posts in the courses supported by the Instagram application and the students 'use of Instagram, and there was no significant difference between the groups' mean scores. In other words, it has been observed that the variable of using Instagram does not have an effect on students' attitude levels towards the type and purpose of the Instagram posts.

General thoughts on the quality of the sharing for the learning process were expressed qualitatively by 123 participants and the collected data were analyzed with the NVivo program. 
As a result of the analysis, 85 participants stated that the posts have beneficial and motivating contributions to the learning process. While 2 people stated that it was intriguing, 21 people stated that they touched on the important points that were overlooked in the preparations for the exam, and that giving the formulas in a different way is useful for remembering. 15 people made suggestions about the quality of the sharing for the learning process. Statements that stand out from the given suggestions can be gathered under the titles such as sharing more challenging examples, video sharing, more posts and continuous posts. Participants also stated that learning processes would become more efficient if this was the case in their other lessons.

General thoughts on the quality of question and answer activities were expressed by 102 participants. 52 of the participants emphasized that they found satisfactory answers to their questions by saying that the question and answer activities were good and sufficient. 42 participants stated that the question-and-answer activities are of high quality, useful, necessary, and that they gain learning practicality, reinforce and help them remember what they forgot, and shape their working methods. They also stated that these activities paved the way for them not to give up early on the difficulties that they faced. 3 participants stated that their question and answer activities are sincere and relevant, and they reported that they were cared about and motivated. 5 participants made suggestions that these activities should be done more. In addition to these suggestions, students wished that other lecturers should provide this practice for their own courses.

General opinions of 110 participants regarding the necessity of social content sharing were taken and analyzed. As a result of the analysis, 81 participants stated that these shares were necessary and funny and emphasized that they increased efficiency, and motivated before the exam. 13 participants found the posts creative and stated that they increased the interest in the course. In addition, 13 students made suggestions that these shares should be made more frequently. 2 participants stated that social content posts feel like they are interacting directly. Only one of the participants stated that this sharing activity was unnecessary, but did not state the reason. The majority of the participants stated that other lecturers should also do these activities and that all courses would be supported in this way by using the phrase "I wish ..."

\section{Discussion and Conclusion}

As a result of supporting the formal undergraduate courses with social media (Instagram) sharing, this study was conducted with the participation of 180 students who took the courses of Decision Support Systems and Introduction to Algorithm and Programming. In the study, mixed method research method was applied, quantitative and qualitative data were analyzed, and various results were obtained. The results of the study are basically presented in three sections in line with the research questions. When the results related to the attitudes of the students regarding the quality of the posts shared for learning purposes on Instagram are examined, it is seen that there is no significant difference between female and male students, the students taking the DSS and Algorithm course, the status of using / not using the program or the education period of the students.

When the student attitudes towards the type and purpose of the postings for learning purposes on Instagram are examined, female students stated that they found the posts on Instagram more beneficial than the males and they increased their interest in the course. This result has parallels with the study conducted by Yllmazsoy and Kahraman (2017) which stated women use Facebook at a higher level than men for educational purposes. Considering the course-focused, the students who took the DSS course stated that the social posts on Instagram made them feel better and that the different posts (course sharing, live broadcasting and question-answer sharing) were effective 
in finding themselves in the course. This difference between students taking the DSS and Algorithm courses coincides with the conclusion by Çakır and Yalçın (2006) that lecturing given virtually can be applied or theoretical in terms of feasibility and effectiveness. For, the content of these courses and teaching methods are different from each other. Likewise, Menteşe (2013) also mentioned the conclusion that social media environments and tools are not the same for each course. When examining the type and purpose of the postings for educational purposes and the attitude levels of the students with regard to their education period or using / not using, it was seen that there was no statistically significant difference between the groups. However, this result differs from the judgment that the skill levels of students are higher in the tools they use compared to the usage levels of social networking sites in the study of Baran and Ata (2013).

As a result of the qualitative data regarding the quality of the sharing for the learning process, nearly $70 \%$ of the participants stated that the sharing had beneficial and motivating contributions to the learning process. On the other hand, majority of the participants stated that the questionand-answer activities were sincere and relevant, and they felt that they were care about and were motivated. Since this increases the level of social availability of learners, it can be considered as an important teaching process in terms of providing effective learning. Conclusions about the necessity of social content sharing clearly showed that these sharing are absolutely necessary in the learning process and are elements that increase efficiency, make learning fun and increase motivation. This result is in parallel with the result of the study by Menteșe (2013) that the use of social media and tools in education increases the level of education given to students and increases motivation. Nearly $20 \%$ of the participants stated that the shares touched on the important points that were overlooked in their preparations for the exam, and that giving the formulas in a different way is beneficial to remember. In Gülbahar et al.'s study (2010), it was concluded that social media was also effective in increasing student-student, student-content and teacher-student interaction, and to use and develop students' research, inquiry and problem solving skills. In addition, some students made various suggestions about the posts. These suggestions are mostly for the examples to be compelling; for video sharing and continuity of video sharing. In addition, most of the participants stated that the other courses they took should be supported by social media elements. Cooke (2017) stated that students find the use of social media useful in their learning and that they see it as a complementary tool rather than a dominant teaching methodology.

When the results regarding the quality of the question and answer activities are examined, more than half of the participants stated that the question and answer activities are effective and satisfying. In addition, nearly half of the participants stated that social media sharing is necessary for effective learning in the course of the lesson and helps them reinforce their learning processes and remember them and shape their working methods. The fact that Cooke (2017) states that students improve their learning experiences of social media shows similarity to this result. Manca and Ranieri (2016) stated that academics do not tend to integrate social media tools into their applications for various reasons such as cultural resistance, pedagogical issues or institutional restrictions. However, the results regarding the quality of the sharing of the learning process and the question and answer activities and the necessity of the social content sharing have clearly shown that the learning process will become permanent and effective if all the lessons carried out are supported by social media posts. 


\section{References}

Ak, B. (2014). Parametrik hipotez testleri. In Ş. Kalaycı (Ed.), SPSS uygulamalı çok değişkenli istatistik teknikleri (pp. 73-82). Ankara: Asil Yayın.

Altıparmak, M., Kurt, İ. D., \& Kapıdere, M. (2011). E-learning and open source code management systems in education. XI. academic informatics Conference, (pp. 319-327). Malatya.

Baran, B., \& Ata, F. (2013). University students' web 2.0 technologies usage, skill levels and educational usage. Education and Science, 38(169), (pp. 192-208).

Cooke, S. (2017). Social teaching: Student perspectives on the inclusion of social media in higher education. Education and Information Technologies, 22(1), 255-269.

Çakır, H., \& Yalçın, N. (2006). The virtual classroom of system that using internet and intranet. Kastamonu Journal of Education, 14(1), 101-112.

Gleason, B., \& Von Gillern, S. (2018). Digital citizenship with social media: Participatory practices of teaching and learning in secondary education. Journal of Educational Technology \& Society, 21(1), 200-212.

Gülbahar, Y., Kalelioğlu, F., \& Madran, O. (2010). Educational use of social networks. xv. Internet Conference in Turkey. İstanbul.

Güneș, P. U. (2016). The place of social networks in the relationship between social change, technology and education. Açıöğretim Uygulamaları ve Araştırmaları Dergisi, 2(2), 191206.

İnce, M., \& Koçak, M. C. (2017). Social Media Habits of University Students: a Case of Necmettin Erbakan University. Karabük Üniversitesi Sosyal Bilimler Enstitüsü Dergisi, 7(2), 736-749.

Kang, X., \& Zhang, W. (2020). An experimental case study on forum-based online teaching to improve student's engagement and motivation in higher education. Interactive Learning Environments, (pp. 1-12).

Karaman, G. (2010). The effect of written and voice feedback on students satisfaction and success. Master Thesis, Atatürk University, Erzurum.

Manca, S., \& Ranieri, M. (2016). Facebook and the others. Potentials and obstacles of social media for teaching in higher education. Computers \& Education, 95, 216-230.

Mellati, M., \& Khademi, M. (2018). MOOC-based educational program and interaction in distance education: long life mode of teaching. Interactive Learning Environments, (pp. 1-14).

Menteşe, M. (2013). The perspectives of school managers and teachers regarding use of social media tools and platforms in education. Master Thesis, Hacettepe University, Ankara.

Özgür, H., \& Tosun, N. (2010). The Effect of Internet Based Education on E-learning Attitudes. XV. Internet Conference in Turkey, (pp. 2-4).

Shen, J. (2020). Introduction of social media to aid active-learning in medical teaching. Interactive Learning Environments, (pp. 1-8).

Sözbilir, M. (2009). Nitel veri analizi [qualitative data analysis]. Retrieved from http://fenitay. files. wordpress. com

Tengilimoğlu, E., Parıltı, N., \& Yar, C. E. (2015). Social media usage level in the choice of hospital and doctors: Ankara case study. Gazi University Journal of Economics and Administrative Sciences, 17(2), 76-96.

Vural, Z. B., \& Bat, M. (2010). Social media as a new communication environment: A Research on Ege University faculty of communication. Journal of Yasar University, 20(5), 3348-3382.

Yıldız, Y. (2014). The effect of social media on consumer behaviours: The sample of Apple and Samsung. Kastamonu University Journal of Economics and Administrative Sciences, 4(2), 515.

Yllmazsoy, B., \& Kahraman, M. (2017). Investigation of the relationship between social media addiction of university student and social media use for educational purposes: The case of Facebook. Journal of Instructional Technologies \& Teacher Education, 6(1), 9-20. 


\section{APPENDIX A.}

\section{Scale to Identify the level of Student Satisfaction in Social Media-Supported Education}

This questionnaire is created for the purpose of evaluating the Instagram posts made within the scope of the course. The questionnaire consists of four parts. The first part includes demographic information, the second part about the general evaluation judgments about the posts; the third part is the judgments according to the types of the posts, and in the fourth part, there are questions about your opinions about the quality and necessity of the posts. Your answers will be kept confidential and will be used purely for research purposes, in any way; they will not be evaluated as mark, etc,

Demographic Information

Sex

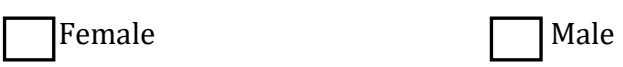

The course you took

Decision Support Systems $\square$ Introduction to Algorithm and Programming

How many years have you been studying in this department?
1
2
3
4

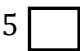
$5+\square$

Frequency of Your Instagram Usage

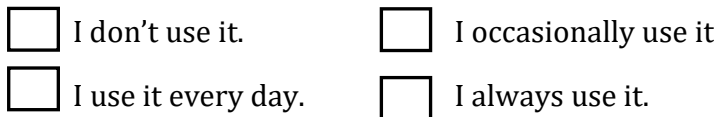

Do you follow Instagram account of the course?

$\square$ Yes

No

Evaluate the shared Instagram posts (the posts uploaded to CIS if you do not have an Instagram account) in terms of the following criteria.

(1) strongly disagree, (2) disagree, (3) partially disagree, (4) Neutral, (5) partially agree, (6) agree, (7) strongly agree

\begin{tabular}{|l|l|l|l|l|l|l|l|}
\hline & 1 & 2 & 3 & 4 & 5 & 6 & 7 \\
\hline It was useful & & & & & & & \\
\hline It was detailed & & & & & & & \\
\hline It was understandable & & & & & & & \\
\hline It was comprehensive & & & & & & & \\
\hline It was sincere & & & & & & & \\
\hline It reflected the truth & & & & & & & \\
\hline It was motivating & & & & & & & \\
\hline It was exhilarating & & & & & & & \\
\hline
\end{tabular}

Specify the degree of agreeing with the views below regarding Instagram shares in the course

(1) strongly disagree, (2) disagree, (3) partially disagree, (4) Neutral, (5) partially agree, (6) agree, (7) strongly agree

\begin{tabular}{|c|c|c|c|c|c|c|c|}
\hline & 1 & 2 & 3 & 4 & 5 & 6 & 7 \\
\hline Instagram live broadcasts help me improve myself. & & & & & & & \\
\hline Instagram storytelling and sharing tips help me improve myself. & & & & & & & \\
\hline Question-and-answer hours on Instagram help me improve myself. & & & & & & & \\
\hline
\end{tabular}




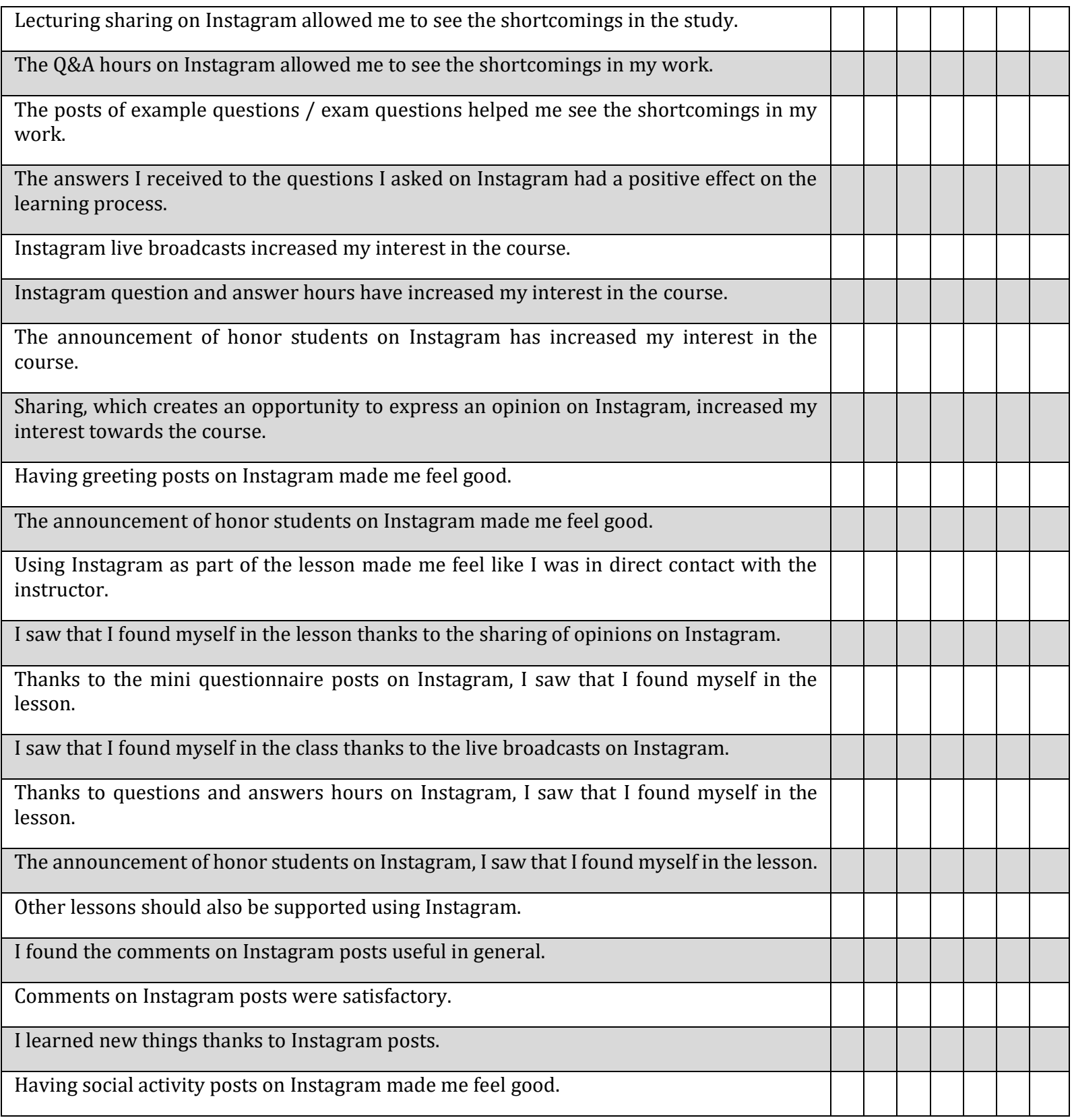

1. Please write your general thoughts on the quality of the posts for the learning.

2. Write your general thoughts on the quality of the question and answer activities.

3. Write your general thoughts on the necessity of social posts.

\section{Etik Beyannamesi}

$\mathrm{Bu}$ makalede "Yükseköğretim Kurumları Bilimsel Araştırma ve Yayın Etiği Yönergesi" kapsamında belirtilen bütün kurallara uyduğumuzu, "Bilimsel Araştırma ve Yayın Etiğine Aykırı Eylemler" başlığı altında belirtilen eylemlerden hiçbirini gerçekleştirmediğimizi, hiçbir çlkar çatışmasının olmadığını ve oluşabilecek her türlü etik ihlalinde sorumluluğun makale yazarlarına ait olduğunu beyan ederiz.

Research article: Karaman, G., \& Özmen, E. (2021). The effect of social media-supported teaching on students satisfaction levels: A case study of Instagram. Erzincan University Journal of Education Faculty, 23(2), 593-612. 